\title{
Decision Support System for Determining the Scholarship Recipients using Simple Additive Weighting (SAW)
}

\author{
Muhamad Ibrohim \\ University of Serang Raya \\ Serang-Cilegon Street \\ KM 3 district taktakan, \\ Serang city, Banten province, \\ Indonesia
}

\author{
Sumiati \\ Univeristy Of Serang Raya \\ Serang-Cilegon Street \\ KM 3 district taktakan, \\ Serang city, Banten province, \\ Indonesia
}

\begin{abstract}
The scholarship is to help ease the cost burden someone less capable or accomplished during his education. In determining the grantee by universities both public and private certainly has criteria to determine who will be elected receive a scholarship. In the process of development of a decision support system to determine the scholarship recipients use traditional methods Simple Additive Weighting (SAW), where this method is able to select the best alternative from a number of alternatives, in this case the alternative meant that the right to receive scholarships based on criteria specified. Research done by finding the weight values for each attribute, then ranking process performed by the intensity of priority to produce a score value terbaik.Penelitian awardees will analyze the determination of the scholarship recipients based intelligent computing systems to help the working team selectors scholarship in performing the selection of scholarship, can accelerate scholarship selection process, can reduce errors in determining the scholarship recipients, and can facilitate team selectors in determining the recipients.
\end{abstract}

\section{Keywords}

Determination Scholarship, Simple Additive Weightin (SAW), Weights

\section{INTRODUCTION}

Scholarship is a program of work that exist in each university with the aim to ease the burden of students in taking the period of education, especially the issue of cost. Determination of the grantee be selectively carried out in accordance with the type of scholarships held, To get the scholarship it must be in accordance with predefined rules. Defined criteria include academic performance index, pengasilan parents, number of siblings, the number of dependent parent, semester and others. Therefore, not all students who apply for the scholarship can be granted because the number of students who apply for the lot and the assessment criteria that much anyway so that the process of selecting the feasibility of the scholarship recipients have problems with the increasing number of students who apply for scholarships and limited personnel selectors receiver scholarship. Based on these problems, to assist in determining the set grantee, it takes a decision support system with methods that can be used is Simple Additive Weighting (SAW), also often known term summation method weighted, the basic concept of Method Simple Additive Weighting (SAW) is seeking a weighted summation of the performance rating for each alternative on all attributes. Simple Additive weighting method requires a process of normalizing the decision matrix $(\mathrm{X})$ to a scale that can be compared with all existing alternative rating. This method was chosen because it is able to select the best alternative from a number of alternatives, in this case the alternative meant that the right to receive scholarships based on criteria specified. Research done by finding the weight values for each attribute, then do ranking process that will determine the optimal alternative.

This study will discuss more focused on the objectives to be achieved, it can be formulated as follows:

- How to determine the criteria and alternatives people who will receive scholarships based on weight and pre-determined criteria?

- How to design a decision support system for receiving a scholarship by using Simple Additive weighting method?

- How does this decision support systems to help and provide an alternative in determining the scholarship recipients, change the criteria, decision-makers on issues related to the grantee, so that the students will get the deserving?

\section{METHODOLOGY}

Determination of the grantee be selectively carried out in accordance with the type of scholarships held, To get the scholarship it must be in accordance with the rules ditetapkan.Langkah SAW Settlement are as follows : Specifies the criteria that will be used as a reference in the decision that $\mathrm{Ci}$ :

- Determine the suitability rating each alternative on each criterion .

- Make decisions based on criteria matrix

( $\mathrm{Ci}$ ), then normalized matrix based on the equations adjusted for the type attribute ( attribute or attributes benefit costs ) in order to obtain the normalized matrix R. The final results obtained from the ranking process is the summation of the matrix multiplication $\mathrm{R}$ normalized with the weight vector thus obtained :

$r i j\left\{\begin{array}{l}\frac{x i j}{M a x x i j} \text { if } j \text { is an attribute profit } \\ \frac{M i n x i j}{x i j} \text { if } j \text { is an attribute cost }\end{array}\right.$

Where :

rij= Rating normalized performance 
Max $x i j=$ The maximum value of each row and column

Min $x i j=$ The minimum value of each row and column

$x i j=$ Rows and columns of the matrix

With $r i j$ is the normalized performance rating of alternatives on attribute $\mathrm{Ai} \mathrm{Cj} ; \mathrm{i}=1,2, \ldots \mathrm{m}$ and $\mathrm{j}=1,2, \ldots, \mathrm{n}$.

Preference value for each alternative (Vi) is given as:

$$
V i=\sum_{j=1}^{n} w j r i j
$$

Where :

$V i=$ The final value of the alternative

$w j=$ Weight predetermined

$r i j=$ Normalization matrix

$V i$ larger value indicates that the alternative is selected.

\section{RESULT}

Input Requirements Analysis

Data processing activities and the selection of scholarship recipients conducted by the personnel of each academic year. The elements on which the scholarship recipients include:

1. To merit scholarship:
a. CPI score $\geq 3: 00$
b. Letter of good conduct from college
c. Minimal term of 2 (two)

2. For scholarship underprivileged:
a. Minimal term of 2 (two)
b. Total income parents
c. The number of dependent parents
d. Attached letter was not capable of villages

Based on the above requirements, the criteria specified by the user, namely:

1. GPA based photocopied transcript GPA

2. Semester based photo copy KRS

3. Income Parents based photo copy of Certificate of Income Parent / Guardian

4. Number of Dependents Parent based photo copy of Family Card

\section{Alternative}

Determine scholarship recipients use

SAW method:

1. Determine the criteria that will be used as reference for decision making $(\mathrm{Ci})$ of the criteria used in making decisions based on the requirements of the applicants for a scholarship are as follows:

$\begin{array}{ll}\text { GPA } & =\mathrm{C} 1 \\ \text { Semester } & =\mathrm{C} 2 \\ \text { Number Dependent Parent } & =\mathrm{C} 3 \\ \text { Income Parents } & =\mathrm{C} 4\end{array}$

The criteria or attributes are divided into two categories, namely benefit (profit) and cost (cost). The criteria are categorized benefit if these criteria will maximize its value while the criteria if the criteria are categorized benefit value will Minimize. The criteria are categorized benefit GPA, Semester and Number of Dependents Parents. While the cost is categorized criteria Income Parents.

2. Determine the suitability rating each alternative on each criteria, of these criteria made an interest rate criterion is based on the weights. Rating suitability of each alternative on each criteria is as follows:

$$
\begin{array}{lll}
\text { Very Low }(\mathrm{SR}) & =0 & (0 ; 25) \\
\text { Low }(\mathrm{R}) & =25 & (0 ; 25 ; 50) \\
\text { Enough }(\mathrm{C}) & =50 & (25 ; 50 ; 75) \\
\text { Height }(\mathrm{T}) & =75 & (50 ; 75 ; 100) \\
\text { Very High }(\mathrm{ST}) & =100 & (75 ; 100)
\end{array}
$$

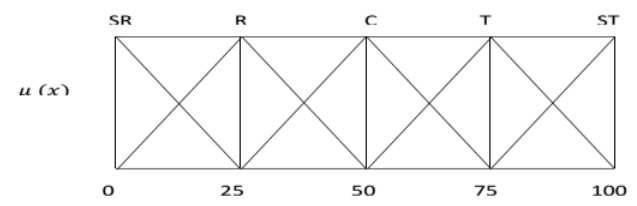

Figure 1. Graph Domain SAW

3. Make a decision matrix based on criteria, then normalizing matrix based on the equation adjusted for the type attribute to obtain the normalized matrix R.

Criteria / Attributes

1. Criteria Value GPA

Criteria GPA visits by students obtained GPA during the study.

Table 1. Value Criteria GPA

\begin{tabular}{|c|c|}
\hline GPA & Weight \\
\hline GPA $2.75-3.00$ & 25 \\
\hline GPA 3.00 - 3.25 & 50 \\
\hline GPA 3.25 - 3.50 & 75 \\
\hline GPA 3.50 & 100 \\
\hline
\end{tabular}

2. Criteria Value Semester

Criteria half of visits by the number of semesters that have been taken by students . Scholarships of Higher Education at the University of Raya Serang usually held every end of the first semester. Scholarships are awarded twice within a period of one year or for two semesters .

Table 2. Criteria Semester

\begin{tabular}{|c|c|}
\hline Semester & Weight \\
\hline Semester 2 & 25 \\
\hline Semester 3 & 50 \\
\hline Semester 4 & 75 \\
\hline Semester 5 & 100 \\
\hline Semester 6 & 100 \\
\hline
\end{tabular}


3. Criteria Number of Dependents Parents

Criterion number of dependent parent visits based on the cost of living that still have to be borne by the parents of the overall number of children

Table 3. Criteria Number of Dependents Parents

\begin{tabular}{|c|c|}
\hline $\begin{array}{c}\text { The number of Dependents } \\
\text { Parents }(\mathbf{T})\end{array}$ & Bobot \\
\hline $\mathrm{T}=1$ child & 25 \\
$\mathrm{~T}=2$ child & 50 \\
$\mathrm{~T}=3$ child & 75 \\
$\mathrm{~T}=4$ child & 100 \\
\hline
\end{tabular}

4. Criteria Income Parents

Criteria income parents seen by the amount of retained earnings or not each month.

Table 4. Criteria Income Parents

\begin{tabular}{|c|c|}
\hline $\begin{array}{c}\text { Income Parents } \\
\text { ( P) }\end{array}$ & Weight \\
\hline P 1.000 .000 & 25 \\
\hline P $1.000 .000-3.000 .000$ & 50 \\
\hline P $3.000 .000-5.000 .000$ & 75 \\
\hline P 5.000 .000 & 100 \\
\hline
\end{tabular}

The final result is obtained from the process of ranking the matrix multiplication is the sum of the normalized $\mathrm{R}$ with a weight vector in order to obtain the greatest value is selected as the best alternative as a solution

\section{Weighting Decision}

Determining the value of a weight vector based on the level of importance of each criterion on a scholarship PPA and BBM . On scholarship PPA most preferred criteria is GPA, then the value of the weight vector PPA $(w l)$ is as follows :

$w 1=\left[\begin{array}{llll}0.40 & 0.30 & 0.20 & 0.10\end{array}\right]$

Table 5 Vector PPA Weight

\begin{tabular}{|c|c|c|c|}
\hline C1 & C2 & C3 & C4 \\
\hline 0.40 & 0.30 & 0.20 & 0.10 \\
\hline
\end{tabular}

While the BBM scholarship criteria are most concerned about are the number of dependents of parents and salaries of the parents, then the value of the weight vector BBM ( w2 ) is as follows :

$w 2=\left[\begin{array}{llll}0.10 & 0.20 & 0.30 & 0.40\end{array}\right]$

Table 6. Vector BBM Weight

\begin{tabular}{|c|c|c|c|}
\hline C1 & C2 & C3 & C4 \\
\hline 0.10 & 0.20 & 0.30 & 0.40 \\
\hline
\end{tabular}

\section{Analysis Calculation Methods}

Suppose in Informatics Engineering Program has a quota for each type of scholarship. If there are three student scholarship applicants , the student is assumed to follow a scholarship PPA and BBM with the following data:

Table 7. Applicant Data

\begin{tabular}{|c|c|c|c|c|}
\hline $\begin{array}{c}\text { Applicant } \\
\text { Name }\end{array}$ & GPA & Semester & $\begin{array}{c}\text { Number of } \\
\text { Dependents } \\
\text { Parents ua }\end{array}$ & $\begin{array}{c}\text { Income } \\
\text { Parents }\end{array}$ \\
\hline $\begin{array}{c}\text { Applicant } \\
1\end{array}$ & 3.21 & 2 & 2 & 4.586 .600 \\
\hline
\end{tabular}

\begin{tabular}{|c|c|c|c|c|}
\hline $\begin{array}{c}\text { Apllicant } \\
2\end{array}$ & 3.45 & 4 & 4 & 2.000 .000 \\
\hline $\begin{array}{c}\text { Applicant } \\
3\end{array}$ & 3.85 & 6 & 4 & 900.000 \\
\hline
\end{tabular}

Based on Table 7 data are converted into a decision matrix as follows :

Table 8. Clarification Criteria Applicant Data

\begin{tabular}{|c|c|c|c|c|}
\hline \multirow{2}{*}{ Alternatif } & \multicolumn{4}{|c|}{ Criteria } \\
\cline { 2 - 5 } & C1 & C2 & C3 & C4 \\
\hline Applicant 1 & 3.21 & 2 & 2 & 4.586 .600 \\
\hline Applicant 2 & 3.45 & 4 & 4 & 2.000 .000 \\
\hline Applicant 3 & 3.86 & 6 & 4 & 900.000 \\
\hline
\end{tabular}

Applicant data into the matrix is represented as follows :

$$
x=\left[\begin{array}{lccc}
50 & 25 & 50 & 75 \\
75 & 75 & 100 & 50 \\
100 & 100 & 100 & 25
\end{array}\right]
$$

Then do the normalization matrix $\mathrm{x}$ to calculate the value of each criterion. Assumed to be a benefit or cost criteria:

\section{Applicant 1}

$$
\begin{aligned}
& r 1=\frac{50}{\operatorname{Max}\left\{\begin{array}{ll}
5075 & 100
\end{array}\right\}}=0.5 \\
& r 2=\frac{25}{\operatorname{Max}\left\{\begin{array}{ll}
5075 & 100
\end{array}\right\}}=0.25 \\
& r 3=\frac{50}{\operatorname{Max}\left\{\begin{array}{lll}
50 & 100 & 100
\end{array}\right\}}=0.5 \\
& r 4=\frac{\operatorname{Min}\left\{\begin{array}{lll}
75 & 50 & 25
\end{array}\right\}}{75}=0.33
\end{aligned}
$$

\section{Applicant 2}

$$
\begin{aligned}
& r 1=\frac{75}{\operatorname{Max}\left\{\begin{array}{ll}
7510050
\end{array}\right\}}=0.75 \\
& r 2=\frac{75}{\operatorname{Max}\left\{\begin{array}{lll}
75 & 10025
\end{array}\right\}}=0.75 \\
& r 3=\frac{100}{\operatorname{Max}\left\{\begin{array}{lll}
100 & 10050
\end{array}\right\}}=1 \\
& r 4=\frac{\operatorname{Min}\left\{\begin{array}{lll}
50 & 25 & 75
\end{array}\right\}}{50}=0.5
\end{aligned}
$$

Applicant 3

$$
\begin{aligned}
& r 1=\frac{100}{\operatorname{Max}\{1005075\}}=1 \\
& r 2=\frac{100}{\operatorname{Max}\{1002575\}}=1 \\
& r 3=\frac{100}{\operatorname{Max}\{10050100\}}=1 \\
& r 4=\frac{\operatorname{Min}\left\{\begin{array}{lll}
25 & 75 & 50
\end{array}\right\}}{25}=1
\end{aligned}
$$

It follows that the results matrix of matrix $\mathrm{x} \mathrm{r}$ normalized as follows :

$$
r=\left[\begin{array}{llcr}
0.5 & 0.25 & 0.5 & 0.33 \\
0.75 & 0.75 & 1 & 0.5 \\
1 & 1 & 1 & 1
\end{array}\right]
$$


Subsequently created matrix multiplication $\mathrm{w} * \mathrm{r}$. The sum of multiplication was done to obtain the value of the best alternative, ie the value of ranking the largest .

If three students are tested based on the provision of scholarships weight vector PPA, the results perangkingan of $\mathrm{w} 1 * \mathrm{r}$ is as follows :

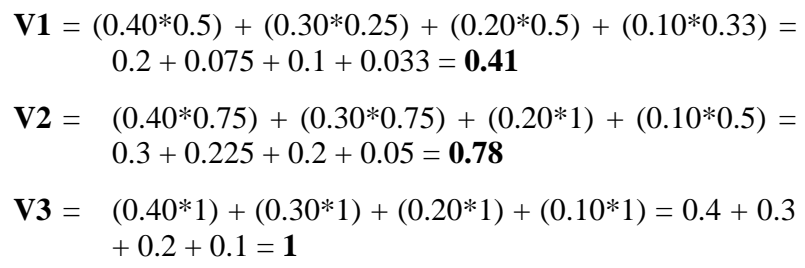

From the results obtained perangkingan V $3=1$ as the greatest value for the weight specified, thus the alternative 3 (Applicant 3) is an alternative that is chosen as the best alternative to get a scholarship fuel.

\section{CONCLUSION}

From the results, analysis and discussion that has been done in this study, some conclusions can be drawn as follows :

1. Decision support system in determining the scholarship recipients at the University of Raya Serang using Simple Additive weighting method ( SAW )

2. This decision support system to help and provide an alternative in the selection of scholarship recipients , change the criteria, decision-makers on issues related to the applicants , so it will get the deserving students scholarships

\section{REFERENCES}

[1] Alireza Afshari, Majid Mojahed dan Rosnah Mohd Yusuf (2010). Simple Additive Weighting Approach to Personnel Selection Problem, Vol.1, No.5, ISSN 20100248 http://ijimt.org/papers/89-M474.pdf
[2] Apriansyah Putra dan Dinna Yunika Hardiyanti (2011). Penentuan Penerima Beasiswa Dengan Menggunakan Fuzzy Multiple Decission Making, Vol.3, No.1, ISSN 2085-

1588http://ejournal.unsri.ac.id/index.php/jsi/article/down $\operatorname{load} / 731 / 273$

[3] Deni Putra (2014). Sistem Pendukung Keputusan Untuk Menentukan Penerima Beasiswa PT. Telkom Menggunakan Metode Simple Additive Weighting, Vol.3, No.2, ISSN 2339-210Xhttp://intibudidarma.com/berkas/jurnal/1.\%20Deni\%20Putra.pdf

[4] Dyah Pratiwi, dkk (2014). Decision Support System to Majoring High School Student Using Simple Additive Weighting Method, Vol.10, No.3, ISSM 22312803http://ijcttjournal.org/Volume10/number-3/IJCTTV10P126.pdf

[5] Efraim Turban, Jay E Aronson, Ting Peng Liang (2006). Decision Support System and Intelligent System, PP.904, Rs.375

[6] Rina Hasanah (2013). Sistem Pendukung Keputusan Untuk Menentukan Penerima Beasiswa Dengan Motode Simple Additive Weighting, Vol.V No.3, ISSN 23019425http://www.pelitainformatika.com/berkas/jurnal/25.\%20rina\%20hasanah.p df

[7] Roger S. Pressman, PhD (2012), Pendekatan Praktisi Rekayasa Perangkat Lunak, Edisi 7, No.1, ISBN 978979-29-3103-7

[8] Sri Eniyati (2011). Perancangan Sistem Penunjang Keputusan Untuk Penerimaan Beasiswa Dengan Metode Simple Additive Weighting, Vol.16, No.2, ISSN 08549524http://download.portalgaruda.org/article.php?article $=7487 \& \mathrm{val}=544$ 